\title{
PENGARUH MINAT BELAJAR TERHADAP KEMAMPUAN MENULIS KARANGAN NARASI PADA SISWA
}

\author{
Hamidah Apriani \\ Program Studi Desain Komunikasi Visual, \\ Fakultas Bahasa dan Seni Universitas Indraprasta PGRI \\ Jl. Nangka 58 Tanjung Barat, Jakarta Selatan, 12530 \\ hamidahapriani09@gmail.com
}

\begin{abstract}
Abstrak
Penelitian bertujuan untuk mengetahui pengaruh minat belajar terhadap kemampuan menulis karangan narasi siswa. Penelitian ini menggunakan metode survei dengan menggunakan teknis analisis korelasional. Sampel penelitian berjumlah 70 orang siswa yang dipilih secara random dari seluruh siswa kelas VII SMP. Teknik analisis statistik yang digunakan adalah statistika deksriptif untuk mencari ratarata, median, modus, standar deviasi dan histogram, dan teknik statistika inferensial yaitu untuk mengetahui besaran skor hubungan dan sumbangan variabel bebas terhadap variabel terikat kemudian dilanjutkan dengan uji $\mathrm{t}$ dan uji $\mathrm{F}$ untuk mengetahui signifikansi hubungan antarvariabel tersebut. Berdasarkan hasil penelitian, dapat disimpulkan bahwa: terdapat pengaruh yang signifikan minat belajar terhadap kemampuan menulis karangan narasi, hal tersebut dibuktikan dengan sig. 0,005 $<0,05$ dan thitung $=2,870$, Artinya, minat belajar terbukti memiliki pengaruh positif terhadap kemampuan menulis karangan narasi siswa.
\end{abstract}

Kata Kunci: Minat Belajar, Kemampuan Menulis Karangan Narasi.

\section{THE INFLUENCE OF LEARNING INTEREST TOWARDS THE ABILITY OF STUDENTS IN WRITING NARRATIVE TEXT}

\begin{abstract}
The aim of this research is to know the students ability of narrative writing. This reseacrh by using the survey method which is using teh correlational analysis. The sample research toward 70 students that randomly by all students of junior high school in class VII. The analysis technique that used is statistic descriptive to stated the average, median, modus, standard of deviation, and histogram, technique stastistic inferential. Stastistical techniques that is so determine the scale of the relationship score and the contribution of independent variables to the dependent variable then proceed with $t$ test and $F$ test that to know the significance of the relationship between these variables. Based on this research we can summarized that: there is significant relation between learning interest toward the ability of writing students, that proved by sig. 0,005 0,05 and thitung $=2,870$ its means that learning interest are proved has the positive impact towards writing students skills of narrative text.
\end{abstract}

Keyword: learning interest, the ability writing narrative text of students.

\section{PENDAHULUAN}

Pendidikan merupakan proses sosialisasi yang dialami oleh setiap orang terutama pada generasi muda. Dalam proses sosialisasi itu terjadi internalisasi dari nilai-nilai yang dijunjung tinggi oleh masyarakat untuk diteruskan oleh generasi yang 
mendatang secara berturut-turut. Mengingat pentingnya pendidikan bagi setiap orang, maka sudah selayaknya jika pendidikan merupakan tanggung jawab bersama antara pemerintah, orang tua, dan masyarakat. Ketiga komponen tersebut harus mampu bekerja sama secara sinergis.

Solusi pemerintah untuk meningkatkan mutu pendidikan adalah menerbitkan UU Nomor 20 Tahun 2003 tentang Sistem Pendidikan Nasional yang tercermin dalam rumusan Visi dan Misi Pendidikan Nasional. Untuk mewujudkan visi dan menjalankan misi pendidikan nasional tersebut, diperlukan suatu acuan dasar oleh setiap penyelanggara dan satuan pendidikan, antara lain meliputi kriteria minimal berbagai aspek yang terkait dengan penyelenggaraan pendidikan. Acuan dasar tersebut merupakan standar nasional pendidikan yang dimaksudkan untuk memacu pengelola, penyelenggara, dan satuan pendidikan agar dapat meningkatkan kinerjanya dalam memberikan layanan pendidikan yang bermutu.

Di era globalisasi sekarang ini pelaksanaan sistem pendidikan semakin beraneka ragam bentuknya. Sistem pembelajarannyapun ikut berkembang seiring dengan kemajuan teknologi komunikasi dan informasi. Bahasa adalah salah satu alat komunikasi. Melalui bahasa, kita dapat saling berhubungan (komunikasi), saling berbagi pengalaman, saling belajar dari yang lain dan dapat meningkatkan kemampuan intelektual. Keberadaan bahasa menyebabkan manusia dapat memahami dan mengungkapkan informasi, pikiran, perasaan, serta mengembangkan ilmu pengetahuan, teknologi, budaya, dan memperluas wawasan berpikir. Maka pelajaran Bahasa dan Sastra Indonesia adalah program untuk mengembangkan pengetahuan, keterampilan berbahasa dan sikap positif terhadap bahasa Indonesia.

Dengan demikian tidak dapat dipungkiri betapa pentingnya bahasa bagi kehidupan manusia terutama sebagai sarana untuk berkomunikasi baik secara lisan maupun tulisan. Komunikasi dalam bentuk tulisan tentu menuntut para pembelajar untuk terampil dalam menuangkan ide dan pikiran dalam bentuk tulisan untuk menciptakan komunikasi secara tidak langsung, sehingga apa yang tertuang dapat dimengerti dan bermakna bagi para penikmat tulisan tersebut. Untuk menciptakan karya tulis yang sarat makna tentunya para penulis harus terampil dan mengerti aturan-aturan dalam hal menulis.

Sehubungan dengan penggunaan bahasa, terdapat empat keterampilan dasar berbahasa, yaitu mendengarkan (menyimak), berbicara, membaca, dan menulis (Mulyati, 2008:1.10). Setiap keterampilan itu erat sekali berhubungan dengan tiga keterampilan lainnya dengan cara yang beraneka ragam. Dalam memeroleh keterampilan berbahasa, biasanya melalui suatu hubungan urutan yang teratur: mulamula pada masa kecil, seorang anak belajar menyimak bahasa, kemudian berbicara, sesudah itu belajar membaca dan menulis. Keempat keterampilan tersebut pada dasarnya merupakan satu kesatuan, merupakan catur-tunggal (Tarigan, 2008:1).

Menulis merupakan salah satu keterampilan berbahasa, yaitu suatu cara berkomunikasi antara individu dengan individu lainnya. Melalui tulisan, seseorang dapat menceritakan kembali kejadian atau pengalaman yang pernah dialaminya, melukiskan sesuatu yang pernah dilihat, dirasa, diraba, dan didengarnya. Melalui tulisan, seseorang juga dapat menyampaikan gagasan, ide, 
dan pikirannya. Berdasarkan pengalaman sebagai pengajar, dari keempat keterampilan tersebut, jika diperhatikan sisi terlemah yang dialami siswa adalah aspek keterampilan menulis.

Kita dapat melihat bahwa pekerjaan menulis bukan hal yang mudah, tentunya tidak dapat dilakukan oleh semua individu, disamping memerlukan pengetahuan yang cukup dalam hal menulis, juga keterampilan dan minat seseorang pada bidang ini juga turut berperan untuk dapat menciptakan suatu tulisan yang bermakna, baik bagi penulisnya maupun pembaca tulisan itu sendiri.

Menulis karangan narasi merupakan salah satu kompetensi dasar dari kemampuan bersastra kelas VII SMP. Siswa diharapkan mampu mengungkapkan pikiran, gagasan, dan perasaan dalam bentuk karya sastra yaitu dalam menulis karangan narasi. Dalam menulis perlu memilih bahasa yang bisa mewakili perasaan, pikiran, dan keinginan, yang dituangkan dalam bentuk cerita, tetapi dalam pengajaran bahasa Indonesia, materi yang dirasa sulit oleh para siswa justru menulis terutama menulis karangan narasi. Maka atas dasar inilah penulis meneliti tentang karangan narasi siswa SMP kelas VII.

Lebih lanjut seperti yang dikemukakan Iskandarwassid dan Sunendar (2011:248), bahwa dibandingkan dengan tiga kemampuan berbahasa yang lain, kemampuan menulis lebih sulit dikuasai bahkan oleh penutur asli bahasa yang bersangkutan sekalipun. Hal ini disebabkan kemampuan menulis menghendaki penguasaan berbagai unsur kebahasaan dan unsur di luar bahasa itu sendiri yang menjadi isi tulisan.

Kemampuan menulis karangan narasi tidak lahir begitu saja tetapi sebelumnya siswa harus belajar, memiliki kemauan, kemampuan dan pengalaman serta minat yang sungguhsungguh untuk menggali ide cerita, sehingga siswa mampu untuk menulis karangan narasi. Kenyataannya pada siswa SMP ada gejala tidak semua memiliki kemampuan mengarang narasinya memuaskan. Keadaan inilah yang membuat penulis tertarik untuk melakukan penelitian pada siswa SMP.

\section{METODE PENELITIAN}

Penelitian dilakukan pada SMP Swasta di Kota Bogor. Sedangkan objek penelitian atau yang akan menjadi sasaran dalam penelitian ini adalah siswa-siswa kelas VII SMP tersebut. Pelaksanaan penelitian dijadwalkan selama empat bulan yang terhitung dari mulai persetujuan proposal dan diperkirakan mulai bulan Februari 2016 sampai dengan bulan April 2016. Waktu penelitiannya dilaksanakan pada semester II (genap) tahun ajaran 2015/2016.

Penelitian ini menggunakan metode kuantitatif dengan mengkaji fakta-fakta yang terjadi secara empiris. Penelitian ini dikategorikan sebagai penelitian deskriptif korelasional karena berusaha memaparkan hubungan faktor atau variabel-variabel yang memengaruhi keadaan tanpa memanipulasi variabel tersebut.

Data-data dalam penelitian ini diperoleh berdasarkan angket minat belajar bahasa Indonesia dan pemberian instrumen kemampuan menulis karangan narasi pada siswa SMP Swasta di Kota Bogor.

Teknik analisis dalam penelitian ini dilakukan melalui analisis korelasi dan regresi guna melihat pengaruh variabel bebas (X) terhadap (Y). Adapun model konstelasi dari hubungan 
antar variabel pada penelitian ini adalah sebagai berikut:

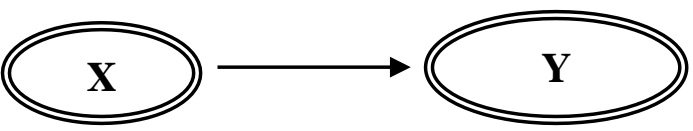

Gambar 1. Model Konstelasi dari hubungan antara variabel.

Keterangan :

Variabel X : Minat Belajar

VariabelY : Kemampuan Menulis Karangan Narasi

Populasi target penelitian adalah seluruh objek dengan karakterisik tertentu yang terdapat dalam daerah penelitian. Populasi dalam penelitian ini adalah para siswa kelas VII yang berada di SMP Swasta di Kota Bogor pada tahun ajaran 2015/2016 yang masingmasing sekolah mempunyai 9 kelas dengan jumlah siswa sebanyak 470 siswa.

Dalam penelitian ini digunakan teknik pemilihan sampel yang menggunakan teknik gabungan antara cluster, proporsional dan random. Teknik cluster digunakan dalam pengelompokan siswa menurut tempat sekolah belajar. Dalam menentukan jumlah anggota sampel digunakan teknik proporsional dari setiap kelas yang ada pada populasi. Sedangkan untuk menentukan anggota sampel dari setiap kelas yang ada digunakan teknik random. Jumlah anggota sampel dalam penelitian ini ditetapkan sebanyak 70 siswa, yaitu sebanyak $15 \%$ dari jumlah populasi (470 siswa). Jadi penetapan jumlah anggota sampel dari setiap sekolah atau cluster sebanyak 35 siswa.

Secara rinci sumber data dalam penelitian ini adalah:

1. Untuk minat belajar $(\mathrm{X})$ berasal dari jawaban responden atas angket yang diberikan oleh peneliti.
2. Untuk kemampuan menulis karangan narasi (Y) berasal dari pemberian tes instrumen soal yang diberikan oleh peneliti.

\section{HASIL DAN PEMBAHASAN}

\section{HASIL PENELITIAN \\ Deskripsi Data}

Jumlah responden dalam penelitian di SMP Swasta di Kota Bogor sebanyak 70 orang siswa yang dijadikan sampel penelitian dan 20 orang siswa sebagai responden untuk uji coba instrumen. Data hasil penelitian dapat ditampilkan dalam bentuk statistika deskriptif secara berurutan sebagai berikut:

\section{Data Variabel Kemampuan Menulis Karangan Narasi (Y)}

Dari hasil penelitian ke lapangan dengan melakukan tes terhadap sampel penelitian yang berjumlah 70 siswa diperoleh rentang skor interval antara 30 sampai 81, rata-rata skor 67,42 , median 67,50, modus 66,00 dan standar deviasi sebesar 6,85 . Hasil perhitungan lengkap dapat dilihat pada tabel berikut:

Tabel 1. Perhitungan Statistika Deskriptif Variabel Menulis Karangan Narasi

\begin{tabular}{|l|r|}
\hline & \multicolumn{1}{|c|}{ Y } \\
\hline N $\quad$ Valid & 70 \\
Mean & 0 \\
Median & 67.4286 \\
Mode & 67.5000 \\
Std. Deviation & $66.00^{\mathrm{a}}$ \\
Variance & 6.85581 \\
Range & 47.002 \\
Maximum & 30.00 \\
Sum & 81.00 \\
\hline
\end{tabular}


Bentuk sebaran data penelitian tersebut di atas, dapat digambarkan dalam histogram sebagai berikut:

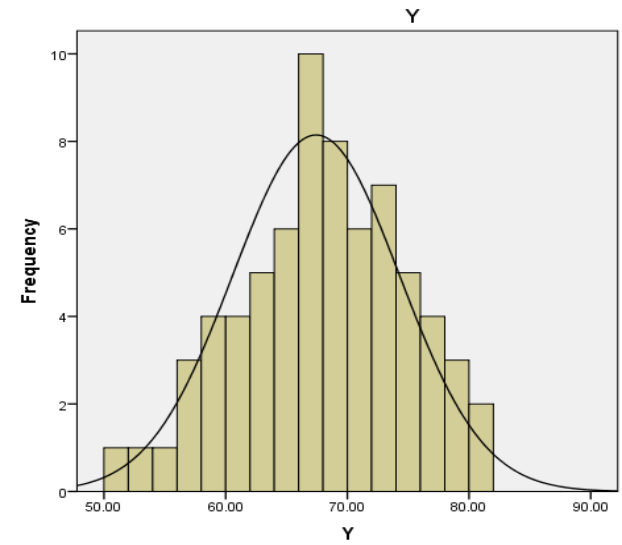

Gambar 2.

Grafik Menulis Karangan Narasi

Pada gambar histogram di atas terlihat seimbang antara jumlah responden yang memiliki skor rendah dengan responden yang memiliki skor tinggi sehingga membentuk kurva normal atau dapat dikatakan bahwa data hasil penelitian variabel kemampuan menulis karangan narasi siswa berdistribusi normal.

\section{Data Variabel Minat Belajar (X)}

Dari hasil penelitian ke lapangan dengan melakukan penyebaran angket terhadap sampel penelitian yang berjumlah 70 siswa diperoleh rentang skor interval dari 28 sampai 68, ratarata skor (Mean) 52,32; modus (Modus) 51,00; median (Median) 52,00 dan standar deviasi (Std) sebesar 6,80. Hasil perhitungan lengkap dapat dilihat pada tabel berikut:

Tabel 2. Perhitungan Statistika Deskriptif Variabel Minat Belajar

\begin{tabular}{|l|r|}
\hline & \multicolumn{1}{|c|}{ X } \\
\hline N $\quad$ Valid & 70 \\
\multicolumn{1}{|c|}{ Missing } & 0 \\
Mean & 52.3286 \\
Median & 52.0000
\end{tabular}

\begin{tabular}{|l|r} 
Mode & $51.00^{\mathrm{a}}$ \\
Std. Deviation & 6.80520 \\
Variance & 46.311 \\
Range & 28.00 \\
Maximum & 68.00 \\
Sum & 3663.00 \\
\hline
\end{tabular}

Bentuk sebaran data penelitian tersebut di atas, dapat digambarkan dalam histogram sebagai berikut:

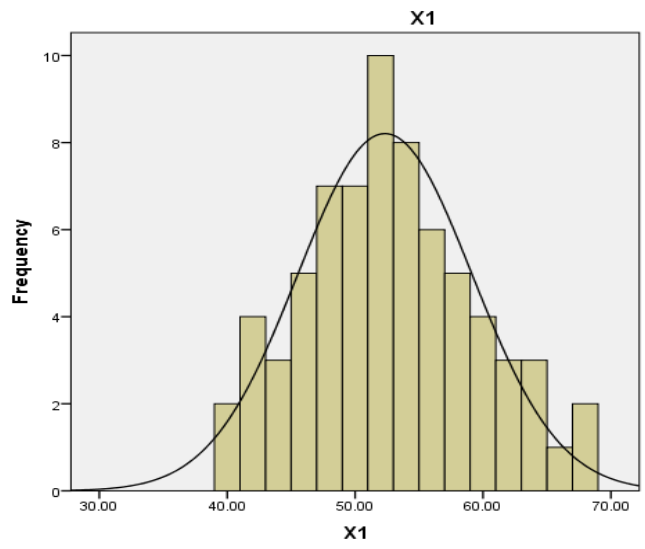

Gambar 3. Grafik Minat Belajar

Pada gambar histogram di atas terlihat seimbang antara jumlah responden yang memiliki skor rendah dengan responden yang memiliki skor tinggi sehingga membentuk kurva normal atau dapat dikatakan bahwa data hasil penelitian variabel minat belajar berdistribusi normal.

\section{Pengujian Hipotesis Penelitian}

Untuk melakukan uji hipotesis, maka perlu ditampilkan tabel hasil perhitungan sebagai berikut:

Tabel 3. Koefisien Korelasi Pengaruh Variabel X (Minat Belajar) terhadap Variabel Y (Menulis Narasi)

\begin{tabular}{|l|r|r|r|c|}
\hline & \multicolumn{6}{|c|}{ Model Summary } \\
\hline Model & $\mathrm{R}$ & R Square & $\begin{array}{c}\text { Adjusted R } \\
\text { Square }\end{array}$ & $\begin{array}{c}\text { Std. Error of the } \\
\text { Estimate }\end{array}$ \\
\hline 1 & $.441^{\mathrm{a}}$ & .194 & .170 & 6.24583 \\
\hline
\end{tabular}

Pada tabel 3. diperoleh skor koefisien korelasi yang menunjukkan hubungan antar variabel bebas dengan 
variabel terikat adalah 0,441 , skor koefisien determinasi yang menunjukkan jumlah kontribusi variabel bebas terhadap variabel terikat sebesar 0,194 atau sama dengan 19,4\%.

Tabel 4. Anova Persamaan Regresi Pengaruh Variabel X (Minat Belajar) terhadap Variabel Y (Menulis Narasi)

ANOVA $^{2}$

\begin{tabular}{|rr|r|r|r|r|r|}
\hline \multicolumn{2}{|l|}{ Model } & \multicolumn{1}{|c|}{$\begin{array}{l}\text { Sum of } \\
\text { Squares }\end{array}$} & Df & Mean Square & F & Sig. \\
\hline $1 \quad$ Regression & 629.449 & 2 & 314.724 & 8.068 & $.001^{\circ}$ \\
& $\begin{array}{r}\text { Residual } \\
\text { Total }\end{array}$ & 2613.694 & 67 & 39.010 & & \\
& 3243.143 & 69 & & & \\
\hline
\end{tabular}

Pada tabel 4. diperoleh sig. 0,001

dan $F$ hitung 8,068 yang berarti koefisien regresi variabel bebas dengan variabel terikat sangat signifikan.

Tabel 5. Signifikansi Koefisien Regresi Pengaruh Variabel X (Minat Belajar) terhadap Variabel Y (Menulis Narasi) Coefficients $^{2}$

\begin{tabular}{|c|c|c|c|c|c|c|}
\hline \multirow{2}{*}{\multicolumn{2}{|c|}{ Model }} & \multicolumn{2}{|c|}{$\begin{array}{l}\text { Unstandardized } \\
\text { Coefficients }\end{array}$} & \multirow{2}{*}{$\begin{array}{c}\begin{array}{c}\text { Standardized } \\
\text { Coefficients }\end{array} \\
\text { Beta }\end{array}$} & \multirow[b]{2}{*}{$\mathrm{t}$} & \multirow[b]{2}{*}{ Sig. } \\
\hline & & B & Std. Error & & & \\
\hline 1 & (Constant) & 37.893 & 7.494 & & 5.057 & .000 \\
\hline & Minat Belajar & .328 & .114 & .326 & 2.870 & .005 \\
\hline
\end{tabular}

Pada tabel 5. diperoleh skor persamaan regresi, koefisien korelasinya $\hat{\mathrm{Y}}=37,89+0,328 \mathrm{X}$, skor $\mathrm{t}$ hitung variabel $X=2,870$ yang menunjukkan adanya hubungan variabel bebas dengan variabel terikat.

Hipotesis penelitian pengaruh minat belajar terhadap kemampuan menulis karangan narasi adalah "Terdapat pengaruh positif minat belajar terhadap kemampuan menulis karangan narasi." Untuk membuktikan hipotesis yang diuji dengan memperhatikan skor pada yang tertera pada kolom " $t$ " atau kolom Sig. tabel di atas. Menurut ketentuan bahwa jika skor Sig. > 0,05 maka Ho diterima artinya regresi tidak signifikan, jika sebaliknya skor Sig. < 0,05 maka Ho ditolak artinya regresi signifikan. Apabila t hitung lebih besar dari t tabel dan skor Sig. 0,000 < 0,05 maka Ho ditolak dan $\mathrm{Ha}$ diterima yang berarti koefisien regresi signifikan, sedangkan bila sebaliknya maka regresi tidak signifikan.

Hasil pengujian keberartian atau signifikansi koefisien korelasi sederhana dijelaskan pada tabel di atas, diperoleh sig. $0,005<0,05$ dan $t_{\text {hitung }}=$ 2,870, maka Ho ditolak dan Ha diterima, artinya terdapat pengaruh minat belajar terhadap kemampuan menulis karangan narasi yang signifikan.

Dari hasil perhitungan koefisien korelasi di atas, dapat disimpulkan bahwa terdapat pengaruh positif dan signifikan minat belajar terhadap kemampuan menulis karangan narasi siswa. Artinya jika kita hendak meningkatkan kemampuan menulis karangan narasi siswa, maka terlebih dahulu harus ditingkatkan minat belajar siswa terhadap pelajaran Bahasa Indonesia.

\section{PEMBAHASAN}

Hasil penelitian menunjukkan terdapat pengaruh minat belajar terhadap kemampuan menulis karangan narasi siswa signifikan, artinya bahwa setiap kenaikan satu skor minat belajar akan diikuti dengan kenaikan kemampuan menulis karangan narasi siswa. Temuan penelitian ini memberikan penegasan baik secara teoritik maupun empirik bahwa minat belajar memberikan pengaruh positif terhadap peningkatan kemampuan menulis karangan narasi siswa.

Uraian di atas, sejalan dengan ungkapan Usman Uzer (2010:27) menjelaskan bahwa minat mempunyai andil yang sangat besar dalam menunjang keberhasilan. Seseorang akan memetik hasil belajarnya ketika ia berminat terhadap sesuatu yang ia pelajari dan dengan sendirinya ia akan menunjukkan keaktifan dalam 
mengikuti pelajaran, oleh karena itu minat siswa merupakan faktor utama yang menentukan derajat keaktifan belajar siswa.

Berdasarkan penjelasan di atas, dapat disimpukan bahwa minat belajar memiliki pengaruh positif terhadap peningkatan kemampuan menulis karangan narasi siswa.

\section{PENUTUP}

Berdasarkan deskripsi data penelitian dan dilakukan setelah analisis maka dapat disimpulkan bahwa terdapat pengaruh yang signifikan minat belajar terhadap kemampuan menulis karangan narasi siswa SMP Swasta di Kota Bogor. Hal ini dibuktikan dengan sig. $0,005<0,05$ dan $t_{\text {hitung }}=2,870$.

Dengan demikian, minat belajar terbukti memiliki pengaruh positif terhadap kemampuan menulis karangan narasi siswa SMP swasta di Kota Bogor. Sedangkan dari perhitungan analisis regresi diperoleh persamaan garis regresi: $\hat{\mathrm{Y}}=37,89+0,328 \mathrm{X}$.

Berdasarkan simpulan hasil pengujian hipotesis penelitian dan analisis pengolahan data, maka implikasi dalam penelitian ini sebagai berikut: hasil penelitian menunjukkan pengaruh signifikan minat belajar siswa terhadap kemampuan menulis karangan narasi. Oleh karena itu, untuk meningkatkan kemampuan siswa dalam hal menulis karangan narasi dapat dilakukan dengan meningkatkan minat belajar siswa.

Upaya meningkatkan minat belajar siswa ialah guru harus menciptakan kegiatan pembelajaran yang aktif, kreatif, dan menyenangkan di dalam kelas. Sehingga pembelajaran mudah dipahami dan diterima oleh siswa. Apabila minat belajat siswa meningkat, maka siswa akan berupaya untuk mendapatkan nilai pelajaran bahasa Indonesia, terutama nilai menulis karangan narasi secara optimal.

Pada bagian akhir dalam penulisan ini, penulis ingin memberikan saran-saran terkait dengan hasil temuan penelitian sebagai berikut :

1. Kepada seluruh guru mata pelajaran Bahasa Indonesia agar banyak menggunakan metode pembelajaran yang interaktif dan menyenangkan sehingga mendorong minat belajar siswa sehingga mereka akan berpartisipasi aktif selama pembelajaran dan pada akhirnya proses belajar mengajar berhasil mencapai tujuan.

2. Kepada kepala sekolah, agar memberikan peluang dan dukungan kepada seluruh guru untuk dapat mengembangkan kompetensinya dengan penggunaan metode pembelajaran kolaboratif dan interaktif seiring dengan perkembangan dan perubahan zaman.

\section{DAFTAR PUSTAKA}

Depdiknas. (2003). Undang-undang RI No. 20 tahun 2003 tentang sistem pendidikan nasional.

Mulyati, Y. dkk. (2008). Keterampilan berbahasa Indonesia. Jakarta: Universitas Terbuka.

Suhendar. (2002). Panduan efektif belajar menulis. Bandung: Angkasa.

Tarigan, H. G. (2008). Menulis sebagai suatu keterampilan berbahasa. Bandung: Angkasa.

Uzer, U. (2010). Menjadi guru profesional, Cet 20. Bandung: Remaja Rosda Karya 